\title{
REPRODUCTIVE PATTERNS AND FEEDING HABITS OF THREE NECTARIVOROUS BATS (PHYLLOSTOMIDAE: GLOSSOPHAGINAE) FROM THE BRAZILIAN CERRADO
}

\author{
ZORTÉA, M. \\ Programa de Pós-graduação em Ecologia e Recursos Naturais, Universidade Federal de São Carlos, \\ Via Washington Luís, km 235, C.P. 676, CEP 13565-905, São Carlos, SP, Brazil \\ Correspondence to: Marlon Zortéa, Campus Avançado de Jataí/Universidade Federal de Goiás, BR 364, km 164, \\ Zona Rural, Jataí, GO, CEP 75801-615, Brazil, e-mail: mzortea@ jatai.ufg.br \\ Received December 3, 2001 - Accepted August 27, 2002 - Distributed February 28, 2003
}

(With 5 figures)

\begin{abstract}
The reproductive patterns and feeding habits of three sympatric nectarivorous bats, Glossophaga soricina, Anoura caudifera, and A. geoffroyi were studied in the Pousada das Araras Natural Reserve, located in Central Brazil. The bats were captured with mist nets from August 2000 to July 2001. Reproductive condition was determined by external analyses of the specimens and feeding habits from fecal samples. Glossophaga soricina was the most abundant species (65\%), followed by A. geoffroyi (30\%) and A. caudifera (5\%). Significant differences were observed in the sex-ratio of the two more abundant species. Anoura geoffroyi showed a monoestrous pattern; its reproductive peaks occurred between the end of the dry season and the beginning of the rain season. A seasonal bimodal pattern was recorded for $G$. soricina, with pregnant specimens showing one peak observed in the dry season and another in the middle of the rainy season. The reproductive pattern of $A$. caudifera could not be satisfactorily defined because of the small sample size. However, this species apparently has a reproductive cycle similar to that of $G$. soricina. The patterns observed in this study seem to be related with the climate in the Brazilian savanna (Cerrado), with two well-defined seasons (dry and wet). By adjusting the parturition close to or in the rain season the three species could be favoring a greates survival rate for the offspring, since the critical lactation period would then occur in a time of maximum food availability. The three bat species showed a generalist diet, consuming fruits, pollennectar, and arthropods. Significant differences were observed in the diet of $G$. soricina: fruits and arthropods predominated in the dry season and pulp (fruits) in the rainy season. Males and females of this species ate the same items in similar proportions. Although A. geoffroyi has not showed a preference for a specific item, consumption of fruits and arthropods was generally greater than that of pollen.
\end{abstract}

Key words: bats, Glossophaginae, reproduction, feeding habits, Cerrado.

\section{RESUMO \\ Padrões reprodutivos e alimentares de três morcegos nectarívoros (Phyllostomidae: Glossophaginae) numa área de Cerrado do Brasil Central}

Os padrões reprodutivos e alimentares de três espécies simpátricas de morcegos nectarívoros, Glossophaga soricina, Anoura caudifera e A. geoffroyi, foram estudados na Reserva Natural Pousada das Araras no Brasil Central. Os morcegos foram capturados mensalmente durante um ano (agosto de 2000 a julho de 2001), com redes de neblina. Os estágios reprodutivos foram inferidos por intermédio de análises externas dos animais e a dieta, por intermédio da coleta de fezes dos animais. Glossophaga soricina foi a espécie mais abundante (65\%), seguida por A. geoffroyi (30\%) e A. caudifera (5\%). Foram observadas diferenças significativas na razão sexual das duas espécies mais abundantes. Anoura 
geoffroyi apresentou um padrão monoéstrico de reprodução com o pico reprodutivo ocorrendo entre o final da estação seca e o início da estação chuvosa. Um padrão poliéstrico bimodal foi identificado para $G$. soricina, com um pico de fêmeas grávidas observado no final da estação seca e outro na metade da estação chuvosa. O período reprodutivo de $A$. caudifera não pôde ser definido satisfatoriamente em função do pequeno tamanho da amostra. Contudo, essa espécie apresentou aparentemente um ciclo similar a $G$. soricina. Os padrões observados neste estudo parecem estar relacionados à sazonalidade climática do Cerrado, que apresenta duas estações bem definidas (seca e chuvosa). As três espécies, ajustando os picos de nascimentos para a estação chuvosa, poderiam garantir maior sucesso de sobrevivência dos filhotes, visto que o período crítico da lactação estaria ocorrendo numa época de máxima oferta de alimentos. Os morcegos estudados apresentaram dieta generalista, consumindo frutos, pólennéctar e artrópodes. Ocorreu diferença significativa na dieta de $G$. soricina, em que frutos e artrópodes foram os itens predominantes na estação seca, enquanto frutos (polpa) predominou na estação chuvosa. Machos e fêmeas dessa espécie comeram os mesmos itens numa proporção semelhante. Embora $A$. geoffroyi não tenha tido preferência por determinado item específico, frutos e artrópodes foram mais consumidos do que pólen.

Palavras-chave: morcegos, Glossophaginae, reprodução, hábitos alimentares, Cerrado.

\section{INTRODUCTION}

The reproductive period is a critical phase for most living organisms, and has become an area of great interest for biologists. Environmental conditions and endogenous factors are strongly associated with bat reproduction (Wilson, 1979; Neuweiler, 2000). Abiotic factors are considered crucial to the success of reproductive strategies of species in temperate latitudes, where bats have a conspicuous monoestrous pattern with their reproductive cycles closely associated with temperature. The estrus is extended and coincides with hibernation (Racey, 1982). In tropical species however, the reproductive cycles are strongly associated with the rainy season. These combined climatic factors (temperature and rainfall) influence food supply availability, interfering directly with bat reproductive cycles (Fleming et al., 1972; Racey, 1982). While monestry is also observed in some neotropical bats, most species show a polyestrous bimodal pattern (Fleming et al., 1972; Taddei, 1976).

Although generalizations are useful in helping to understand some of the patterns verified in nature, the reproductive strategies in Chiroptera (ca. 1000 species) are quite complex and diverse, and, depending on the latitude and habitat type that bats inhabit, vary within the same family, genus, and even within a species (Bradbury \& Vehrencamp, 1977; Taddei, 1980). Four basic reproductive patterns have been proposed for neotropical bats: 1) seasonal monoestry - a single reproductive peak annually; 2) bimodal seasonal polyestry - two reproductive peaks annually; 3 ) a long reproductive period, with a small period of inactivity; and 4) non-seasonal polyestry reproduction throughout the year.

Considering the large number of bat species in the neotropical region, the information available on reproduction is insufficient. Wilson (1979) reviewed data on phyllostomids, and Racey (1982) showed the effects of environmental factors on bat reproduction. In Brazil, data on reproductive cycles of bats is scarce for most species. Taddei (1976) presented data on reproductive cycles of a bat community from São Paulo, and Taddei (1980) reviewed this aspect of bat biology. Subsequent studies are available for a few species, such as Molossus ater (Marques, 1986), M. molossus (Fabián \& Marques, 1989), Artibeus lituratus (Reis, 1989), Tadarida brasiliensis (Marques \& Fabián, 1994), Anoura geoffroyi (Baumgarten \& Vieira, 1994), and Carollia perspicillata (Mello \& Fernandez, 2000). Reproductive data on bat communities in Brazil was gathered by Trajano (1985) on cave species in São Paulo, Willig (1985) on bats in the Cerrado and Caatinga of northeastern Brazil, and Marques (1985) on Amazonian species.

According to Taddei (1996), there are $c a$. 14 predominantly nectarivorous bat species in Brazil. The glossophagines Glossophaga soricina, Anoura caudifera, and A. geoffroyi are among the most frequent species, being a widely distributed 
throughout Brazil (Eisenberg \& Redford, 1999). Besides pollen-nectar, these species use other food resources, such as fruits, floral parts, and insects (Gardner, 1977).

This work presents data on the reproductive pattern and food habits of three species in a private reserve of Cerrado (broadly defined) in Central Brazil, gathered to identify their reproductive and feeding strategies in an area with well-defined climatic seasons.

\section{MATERIAL AND METHODS}

\section{Study area}

This study was carried out in the Pousada das Araras Natural Reserve, located in Serranópolis Municipality, Goiás State, in Central Brazil ( $\left.18^{\circ} 25^{\prime} \mathrm{S}, 52^{\circ} 00^{\prime} \mathrm{W}\right)$. The reserve has $c a .175$ ha, rising to about 300 ha when including adjacent areas. Altitude varies from 500 to $600 \mathrm{~m}$.

The climate according to Köppen's classification is $A W$ (tropical savannah), characterized by high temperatures and two conspicuous seasons: rainy in summer and very dry in winter. The average monthly temperature ranges from $18^{\circ} \mathrm{C}$ to $24^{\circ} \mathrm{C}$. The dry season occurs from April to September, coinciding with the coldest period. The rainy season is in the hottest months, i.e., from October to March. The annual precipitation is ca. 1,400 $\mathrm{mm}$ (Funatura, 1999).

The study area belongs to the domains of Cerrado (Eiten, 1972) with vegetation composed of Cerrado plants and mesophytic species (Funatura, 1999). Three phytophysiognomic types compose the Reserve: Cerrado (narrowly defined), mesophytic forest, and gallery forest.

\section{Data collection}

Bats were collected on 6-day monthly excursions, from August 2000 to July 2001, except for February 2001. Bats were captured with mistnets ( 8 to 10 nets/night, 6 to $12 \mathrm{~m}$ in length) placed on trails and in open vegetation. Captures were not done on rainy nights. Work was carried out over 60 collecting days with 240 hours/net sampling.

External analyses of males and females were made to identify the reproductive stages. After capture, each animal was placed in an individual cotton bag for one hour, for feces collection. Each bat was subsequently identified and its reproductive condition evaluated: males were classified as non-reproductive (with abdominal testis) or reproductive (scrotal testis); and females as non-reproductive (normal abdomen, nonapparent nipples) or pregnant (pregnancy detected by abdominal inspection); lactating (enlarged nipples, with milk secretion verified by light pressure on the nipples), or post-lactating (no milk produced, hair surrounding the nipples recovering).

Feeding habits were inferred from fecal samples. The feces of the animals were placed on glassine papers for later analyses. Most food items were separated into categories [pollen/nectar, pulp (fruits), fruits (with seeds), and arthropods], with no specific identification attempted. However, samples with seeds were separated into morfospecies, and in some cases identified as to genus. Each different item found in a fecal sample was treated as an individual sample. Besides, the presence of pollen in a bat body and fruit carried by captured animals was considered in the sampling.

After the analyses, each bat was individually marked with numbered plastic rings on the forearm and released.

Statistical analysis followed Sokal \& Rohlf (1981). Chi-square analysis was used to evaluate differences in sex ratio of the species in relation to the expected proportion of $1: 1$, and the $G$ test (log-likelihood ratio) was employed to evaluate differences in food item proportions.

\section{RESULTS}

\section{Reproduction}

A total of 339 individuals of three nectarivorous species were captured, with 19 recaptures (Table 1). Two species showed significant difference in sex ratio (Anoura geoffroyi and Glossophaga soricina), with females occurring in a larger proportion than males. Anoura caudifera had low capture rates, and females tended to outnumber males. Most male specimens of the three species were nonreproductive (Table 2).

Anoura caudifera was not collected in September, December, June, and July. The only three pregnant females of this species were captured in the rainy season (November and January). This data added to one record of a female lactating in October, and one post-lactating observed at the end of May, suggesting that this species can have more than one 
annual birth peak. Three non-reproductive females were recorded at the end of the dry season (August and September). Of the three collected males, only one was reproductive (in May).

Females of A. geoffroyi were collected from August 2000 to April 2001. In the drier months (May to July), this species was not recorded in the Reserve. Anoura geoffroyi clearly exhibited seasonal monestry with a pregnancy peak occurring in September and October, and birth peaks in November and December (months with high rainfall rates) (Figs. 1 and 3). Starting in March, a large predominance of inactive females was registered in the population. Three non-reproductive males were observed in different months (end of July, beginning of September and December).

Two distinct reproductive peaks were identified based on a sample of 130 adult females of G. soricina (Fig. 2). Most pregnant females were observed at the end of the dry season (September) and in the middle of the rainy season (January). Lactating individuals were observed from September to January, with one peak in November (Fig. 3B). In January $80 \%$ of the captured females were post-lactating. After March, most of the females were non-reproductive, although in May some post-lactating individuals were also observed. (Table 2). The few reproductive males were collected in May $(\mathrm{n}=2)$ and July $(\mathrm{n}=1)$.

TABLE 1

Number of individuals, relative abundance, and occurrence of young, males, and females of three nectarivorous bats from Pousada das Araras Natural Reserve, Goiás State.

\begin{tabular}{|l|c|c|c|c|c|c|}
\hline \multicolumn{1}{|c|}{ Species } & Abundance $^{\mathbf{1}}$ & $\begin{array}{c}\text { Relative } \\
\text { abundance (\%) }\end{array}$ & $\begin{array}{c}\text { Number of } \\
\text { young }\end{array}$ & $\begin{array}{c}\text { Number of } \\
\text { males }\end{array}$ & $\begin{array}{c}\text { Number of } \\
\text { females }\end{array}$ & Chi-square $^{2}$ \\
\hline A. caudifera & $13(4)$ & 5 & 0 & 3 & 10 & $3,77^{*}$ \\
\hline A. geoffroyi & $98(10)$ & 30 & 11 & 24 & 74 & $25,51^{* *}$ \\
\hline G. soricina & $228(5)$ & 65 & 45 & 71 & 157 & $32,43 * *$ \\
\hline Total & $339(19)$ & 100 & 56 & 98 & 241 & - \\
\hline
\end{tabular}

1. Values between parentheses indicate the number of recaptures not included in the analysis.

2. Differences in the sex ratio among the species $(* \mathrm{p}=0,052 ; * * \mathrm{p}<0,001)$.

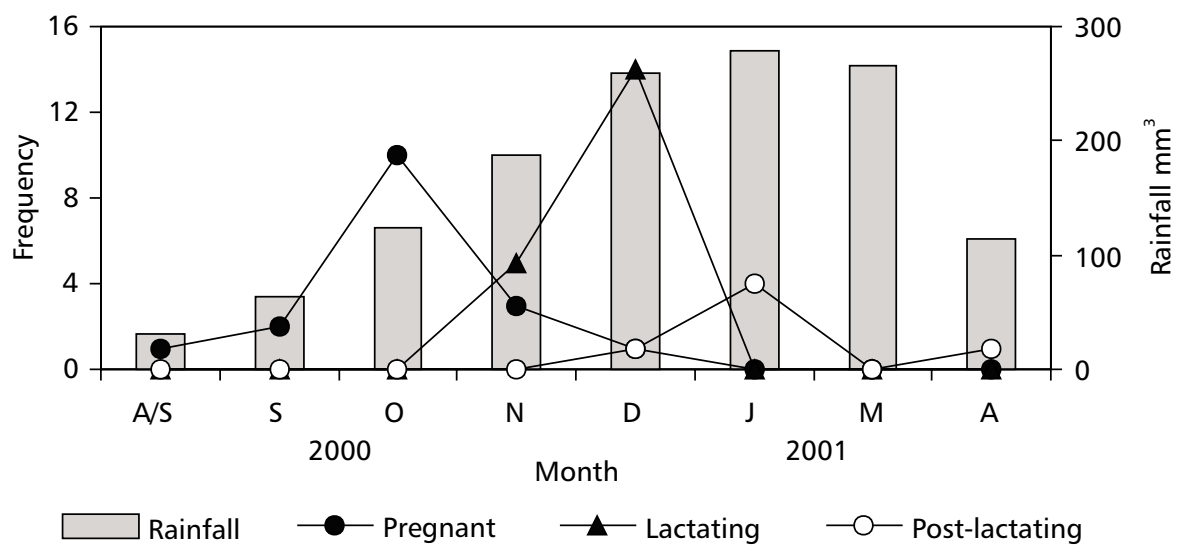

Fig. 1 - Reproductive pattern of 70 females of Anoura geoffroyi in the Pousada das Araras Natural Reserve confronted (bars) with monthly rainfall averages of the region between 1980 and 1999 (INMET/10 DISME - Brazilian National Institute of Meteorology). 
TABLE 2

Reproductive condition of females and males of three glossophagine bats from Pousada das Araras Natural Reserve, Goiás State. Data from recaptured individuals were included in the analysis when the capture interval exceeded one month.

\begin{tabular}{|l|c|c|c|}
\hline \multicolumn{1}{|c|}{ Sex/reproductive condition } & A. caudifera & A. geoffroyi & G. soricina \\
\hline Females & 6 & 28 & 53 \\
\hline Non-reproductive & 3 & 17 & 27 \\
\hline Pregnant & 1 & 19 & 17 \\
\hline Lactating & 3 & 6 & 33 \\
\hline Post-lactating & 2 & 15 & 48 \\
\hline Males & 1 & 3 & 3 \\
\hline Non-reproductive & & & \\
\hline Reproductive &
\end{tabular}

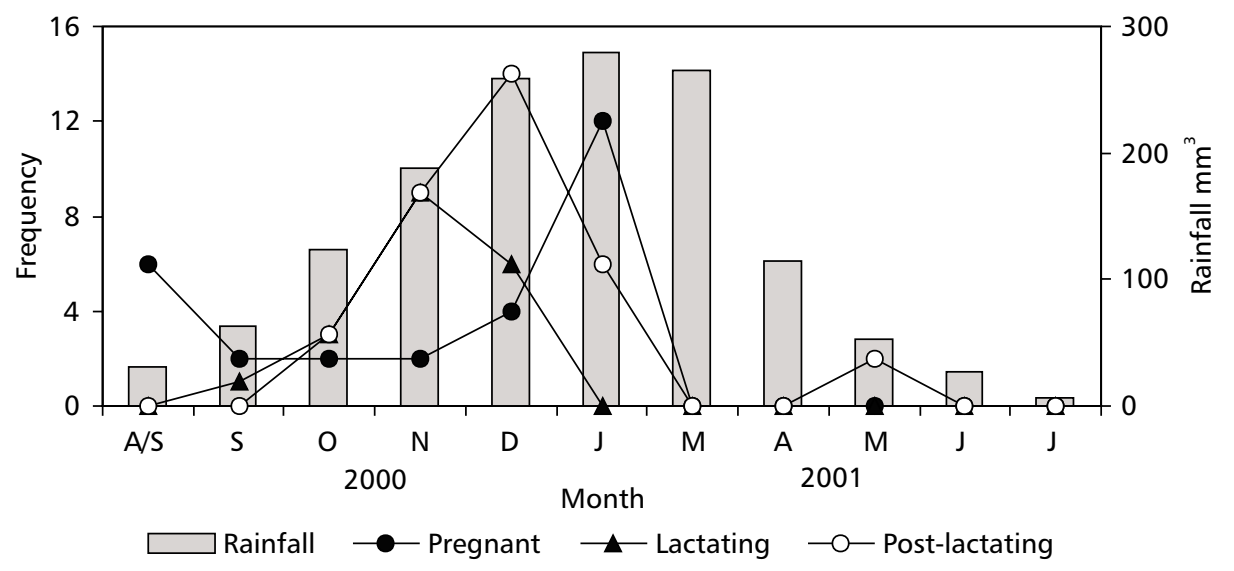

Fig. 2 - Reproductive pattern of 130 females of Glossophaga soricina in the Pousada das Araras Natural Reserve confronted (bars) with monthly rainfall averages of the region between 1980 and 1999.

Comparing the occurrence of all pregnant females of the three species, an asynchronous pattern is suggested, with G. soricina showing its first peak earlier than other species (Fig. 3). In September, G. soricina and A. geoffroyi had a high number of pregnant females, although the peak of A. geoffroyi occurred in October. These two species exhibited pregnancy throughout the dry season, while $A$. caudifera showed pregnancy during the rainy period.

The lactation peak of $G$. soricina occurred one month before that of $A$. geoffroyi. In spite of these differences, the three species had their offspring during the rainy season.

\section{Feeding habits}

The three glossophagine bats presented a diet based on pollen-nectar, fruits, pulp, and arthropods. Only $75(32 \%)$ samples of feces were obtained out of the 233 captures of G. soricina. Fruits and arthropods were most consumed in the two seasons. A significant dietary difference was observed between the dry and rainy seasons $(\mathrm{G}=7.83$; d.f. $=$ $3 ; \mathrm{p}<0.05)$. Glossophaga soricina consumed more arthropods than fruit pulp in the dry season, while in the rainy season the inverse occurred (Fig. 4). Males and females of $G$. soricina consumed the same items in similar proportions $(\mathrm{G}=2.29$; d.f. $=$ $3 ; \mathrm{p}=0.51$ ). 

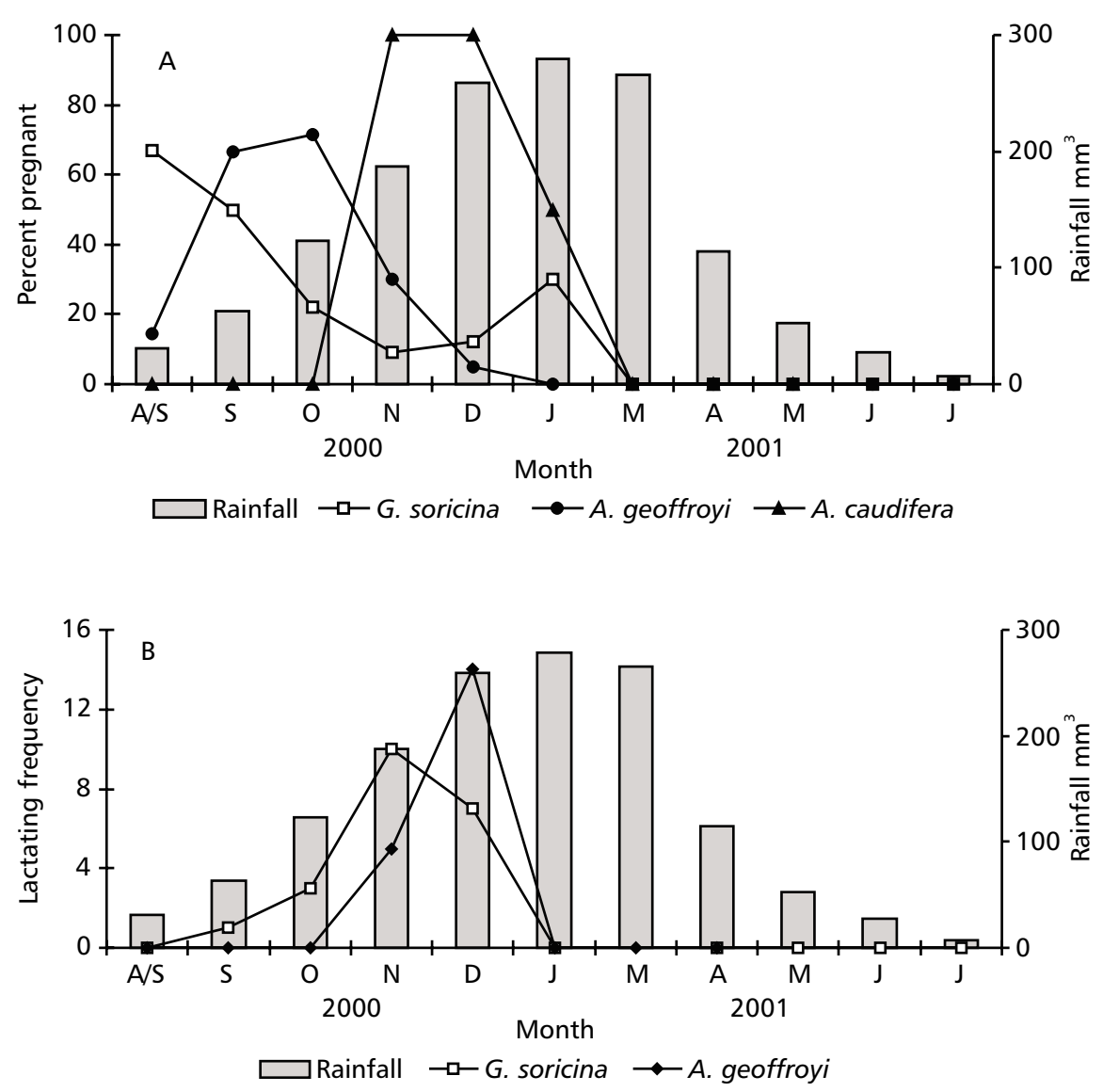

Fig. 3 - Percentage of pregnant females (A) and number of lactating females (B) of three glossophagine bat species of the Pousada das Araras Natural Reserve, confronted (bars) with monthly rainfall averages of the region between 1980 and 1999. Anoura caudifera appears only in graph A.

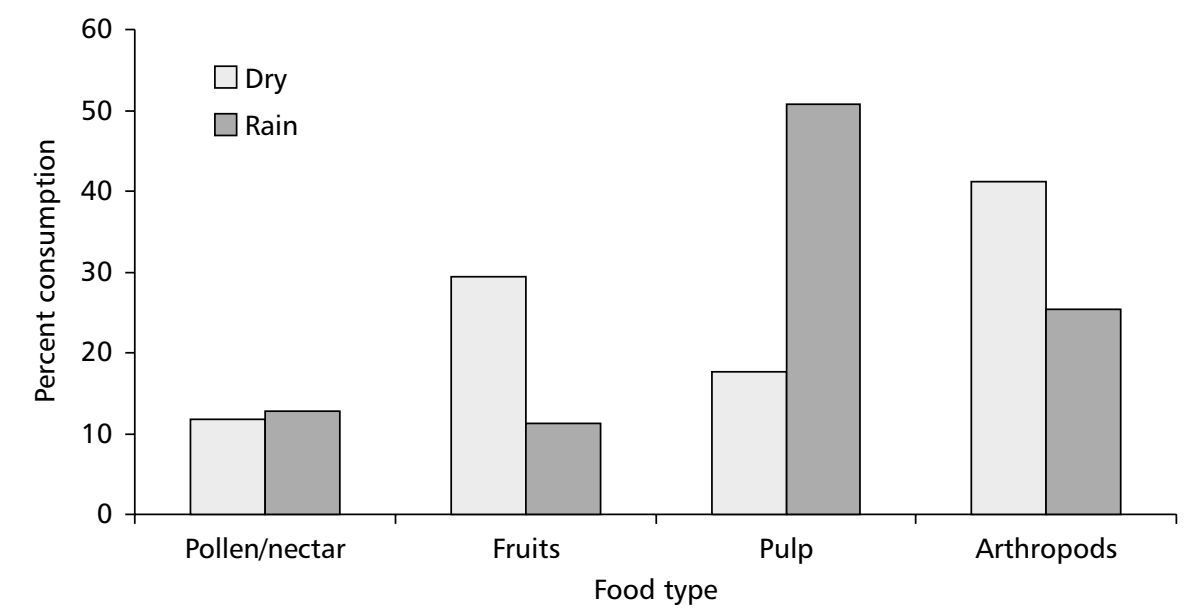

Fig. 4 - Relative abundance of food items consumed in the dry and rainy seasons by Glossophaga soricina from Pousada das Araras Natural Reserve, Goiás State $(n=75)$. 
Four fruit species with seeds were found in the feces of G. soricina, of which only one could be identified at the genus level (Piper, Piperaceae). Casual observations showed that this bat species consumed guava (Psidium sp.) from a small orchard in the Reserve, which was visited in groups of more than 40 bats.

Of the 38 fecal samples examined from $A$. geoffroyi, 36 were obtained in the rainy season. This bat showed no preference for a specific resource but pollen was a rare item compared to fruit pulp and arthropods (Fig. 5). It consumed the same items as those eaten by G. soricina, but in a different way: Anoura geoffroyi seemed to eat insects in a larger proportion than did G. soricina. In the rainy season, most of the diet of A. geoffroyi (> $40 \%$ ) was composed of arthropods, while $G$. soricina ingested this item on a smaller scale: about 25\% (Figs. 4 and 5). The levels of pollen-nectar consumption for the two species were the same (12.7\% and $12.8 \%$ of the total diet of each species).

Anoura geoffroyi consumed at least three species of fruit, of which two were also used by G. soricina (Piper and one unidentified species recorded in October for both species).

Only four samples of feces were obtained from the 17 captures of $A$. caudifera. Two contained insect fragments, one showed fruit pulp, and another, pollen.

Direct observations on the trails of the Reserve revealed the visit of the nectarivorous bats in the flowers of a shrub (Bauhinia sp.). This species blooms in the beginning of the rainy season, and is extremely abundant along the forest edges.

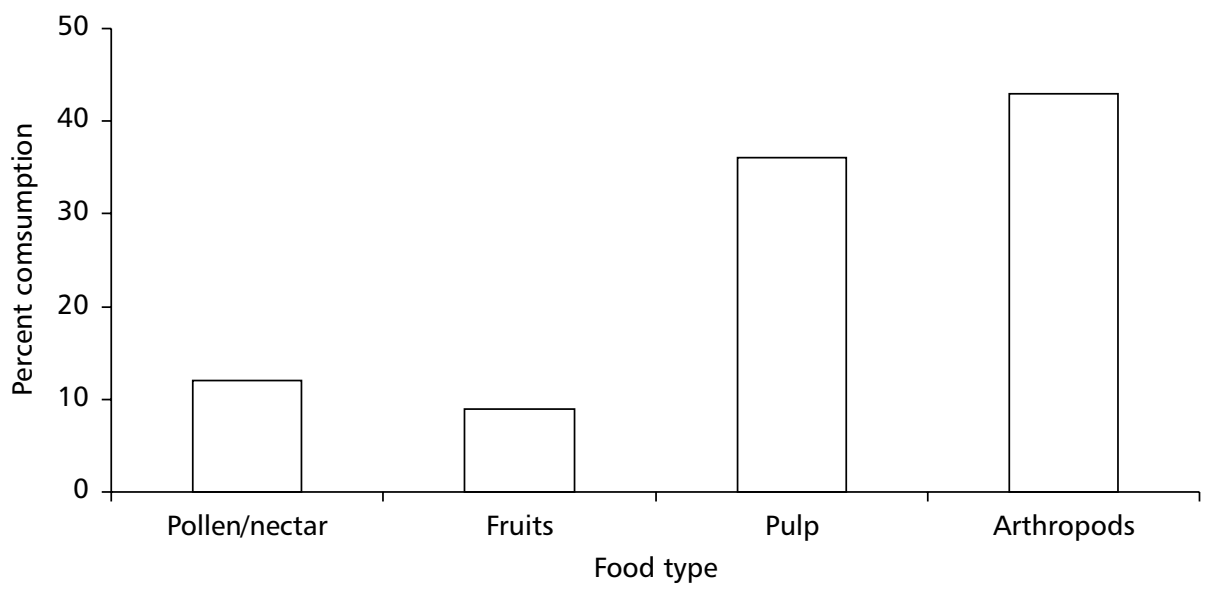

Fig. 5 - Relative abundance of food items consumed by Anoura geoffroyi in the Pousada das Araras Natural Reserve, Goiás State $(\mathrm{n}=38)$.

\section{DISCUSSION}

\section{Reproduction}

In spite of differences in reproductive patterns, all births among the species observed in this study occurred in the rainy season. Some species of seasonal habitats exhibit lactation synchronized with high food availability (Bradbury \& Vehrencamp, 1977), which fits with the fact that this phase is critical to mammals, due to its great energy demand (Racey, 1982). However, there are few studies on bats that measure rainfall effects on food resource availability (e.g., Racey, 1982). Generalized predictions are aggravated by the fact that many species of bats have a wide dietary repertory, with variations occurring among different areas and habitats.

Frugivorous bats from Panama showed synchronization between births and two seasonal peaks of fruit abundance (Bonaccorso, 1979). Litter production in the beginning and end of the rainy season would, therefore, assure high food levels for lactating females and at least the young from 
the first parturition (Fleming et al., 1972; Wilson, 1979). Based on this data, it seems reasonable to assume that nectarivorous bats seek to synchronize their reproductive periods with a season of high food resource availability.

In Central America and southeastern and northeastern Brazil, G. soricina shows bimodal polyestry (Fleming et al., 1972; Taddei, 1976; Willig, 1985). On the other hand, Hamlett (apud Taddei, 1976) showed populations from Mato Grosso (Brazil) exhibiting a unique short reproductive period, while Hernandez et al. (1985) observed aseasonal polyestry of $G$. soricina in Mexico.

Although the bimodal polyestry pattern observed in this study is similar to that found by Fleming et al. (1972) and Willig (1985), reproductive peaks occurred in different periods. Willig (1985) observed one of the two birth peaks of $G$. soricina in the dry season, and Fleming et al. (1972) recorded one of the peaks in the middle of the dry season. The two peaks observed in this study were registered in the rainy season. These data show the high adaptative capacity of $G$. soricina to adjust its reproductive strategies although factors involved in this regulation remain unclear.

Data from Anoura spp. are scarcer. Taddei (1976) observed seasonal polyestry in A. caudifera. The same pattern was suggested for this species in Alto Ribeira, São Paulo (Trajano, 1985). Data from the present study suggest an extended birth period from September to April, with at least one peak occurring in the rainy season (November and December). However, these data are not sufficient to define exactly the reproductive cycle of $A$. caudifera in this region.

The monoestrous pattern verified in this study for A. geoffroyi was the same found for this species in another area of the Brazilian Cerrado (Baumgarten \& Vieira, 1994). These authors observed a single peak of births in the beginning of the rainy season, with lactation synchronized with the flowering of two species of Pseudobombax (Bombacaceae). Anoura geoffroyi showed an extremely generalist diet in this area, however no resource was associated with the reproductive peaks for methodological reasons. However, fruit pulp and arthropods were the most consumed items in the lactation period.

Phenological data on cerrado indicate a variation in the flowering period. However, there is apparently a higher frequency of plants blooming in the end of the dry season (Oliveira, 1998). If this pattern occurs among the chiropterophilous plants in southwestern Goiás State, the period of pregnancy of the three nectarivorous species verified in this study would be synchronized with the high availability of this food resource.

Although the data are insufficient for explaining how food resources can influence bat reproduction, they suggest that the reproductive period is regulated by the proximity of the rainy season, which is theoretically more abundant in food resources such as fruits and insects (Racey, 1982).

A higher proportion of females in relation to males of Glossophaga soricina was observed by Tamsitt \& Valdivieso (1961), Arata \& Vaughn (1970), and Hernandez et al. (1985). This species forms harems, for which the males actively attempt to recruit females (Neuweiler, 2000). These males tend to have smaller home ranges than do females and this factor, added to the high mobility of the females, could be responsible for the discrepency in capture rate. Nevertheless, Taddei (1976) found a sex ratio of $1: 1$, indicating that the pattern observed in the present study could reflect local geographic variation.

\section{Feeding habits}

The data indicate a generalist diet in all three glossophagine bats studied. Although these species are predominantly nectarivorous, apparently pollennectar was not the main resource used. The high incidences of pulp in the fecal samples indicate that most fruits explored by bats in the Cerrado have large seeds.

Glossophaga soricina exhibit a generalist pattern in several regions (Fleming et al., 1972; Heithaus et al., 1975). Rivas-Pava et al. (1996) observed that G. soricina preferred fruits, with pollen and insects being consumed on a smaller scale in Colombia.

The use of Piper fruits has been described for this bat in other areas (Fleming, 1981; Fleming, 1986; Galindo-González, 1998), including the gallery forests of Brazil (Bizerril \& Raw, 1997). In another area of Cerrado, G. soricina used preferentially fruits (60\%, mainly Vismia) and insects (40\%) (Willig et al., 1993), however, for methodological reasons, these authors did not include pollen in their analyses. 
Glossophaga soricina can also exhibit dietary differences in the same area. In comparing the diet of $G$. soricina in two neighboring reserves in Costa Rica (70 km of distance), Fleming (1986) found significant differences in the use of the resources. Fruits of Piper spp. were most consumed in Santa Rosa National Park, while Cecropia peltata (Cecropiaceae) was preferred in La Pacifica.

In spite of a varied diet and the reduced consumption of pollen-nectar verified in the present study, G. soricina plays an important role in the pollination of several neotropical species, including Caryocar brasiliense (Gribel \& Hay, 1993), a typical cerrado plant having high commercial value.

A comparative study between the diet of males and females of G. soricina (Alvarez \& Sánchez-Casas, 1999), showed that the sexes could feed from similar or different resources. These authors affirm that in several areas either sex can exhibit a preference for determined plant species. Although our data have not identified specifically the ingested foods, the proportions of each dietary category were the same for both sexes.

Data on the diet of $A$. geoffroyi and $A$. caudifera are scarce, although both have been mentioned as generalists, feeding largely on insects in certain periods of the year (Gardner, 1977). These two species are the most important pollinating agents of several species in the Atlantic Forest (Sazima et al., 1999). The high consumption of insects and fruits by A. geoffroyi and other nectarivorous bats of the Pousada das Araras Reserve can indicate a low density of chiropterophilous plants in the region. The adaptation to different food items could be a response of the species to the seasonal variation in resource availability, as well as a strategy that minimizes the competition between morphologically and ecologically close species. The differences found in the diet of G. soricina and A. geoffroyi indicate that these species could be selecting different resources, so as to mitigate a possible competitive process among the two species.

Acknowledgments - I thank the staff of Pousada das Araras for allowing access to the study area; the Instituto Brasileiro do Meio Ambiente e dos Recursos Naturais Renováveis for authorizing bat collection (N. 148/2000), and the World Wildlife Fund (Brazil) for financial support in the initial project. I also thank Odete Rocha, Nivaldo Nordi, Manoel M. D. Filho, and one anonymous referee for helpful comments on the manuscript.

\section{REFERENCES}

ALVAREZ, T. \& SÁNCHEZ-CASAS, N., 1999, Diferenciación alimentaria entre los sexos de Glossophaga soricina (Chiroptera: Phyllostomidae) en México. Rev. Biol. Trop., 47(4), on-line.

ARATA, A. A. \& VAUGHN, J. B., 1970, Analyses of the relative abundance and reproductive activity of bats in southwestern Colombia. Caldasia, 10(50): 517-525.

BAUMGARTEN, J. E. \& VIEIRA, E. M., 1994, Reproductive seasonality and development of Anoura geoffroyi (Chiroptera: Phyllostomidae) in central Brazil. Mammalia, 58(3): 415-422.

BIZERRIL, M. X. A. \& RAW, A., 1997, Feeding specialization of two species of bats and the fruit quality of Piper arboreum in a Central Brazilian gallery forest. Rev. Biol. Trop., 45(2): 913-918.

BONACCORSO, F. J., 1979, Foraging and reproductive ecology in a Panamanian bat community. Bull. Flor. State Mus. (Biol. Sci.), 24(4): 359-408.

BRADBURY, J. \& VEHRENCAMP, S., 1977, Social organization and foraging in emballonurid bats. III. Mating systems. Behav. Ecol. Sociobiol., 2: 1-17.

EISENBERG, J. F. \& REDFORD, K. H., 1999, Mammals of the Neotropics. The Central Neotropics. Univ. Chicago Press, Chicago and London, vol. 3, 609p.

EITEN, G., 1972, The cerrado vegetation of Brazil. Bot. Rev., 38: 201-241.

FABIÁN, M. E. \& MARQUES, R. V., 1989, Contribuição ao conhecimento da biologia reprodutiva de Molossus molossus Pallas, 1766 (Chiroptera, Molossidae). Revta. Bras. Zool., 6(4): 603-610.

FLEMING, T. H., 1981, Fecundity, fruiting pattern, and seed dispersal in Piper amalago (Piperaceae), a bat dispersed Tropical shrub. Oecologia, 51: 42-46.

FLEMING, T. H., 1986, Opportunism versus specialization: the evolution of feeding strategies in frugivorous bats, pp.105118. In: A. Estrada \& T. H. Fleming (eds.), Frugivores and seed dispersal. W. Junk Publishers, Dordrecht, 398p.

FLEMING, T. H., HOOPER, E. T. \& WILSON, D. E., 1972, Three Central American bat communities: structure, reproductive cycles and movement patterns. Ecology, 53: 555-569.

FUNATURA, 1999, Plano de manejo Reserva Natural Pousada das Araras. Funatura, Brasília, 215p.

GALINDO-GONZÁLEZ, J., 1998, Dispersión de semillas por murciélagos: su importancia en la conservación y regeneración del bosque tropical. Acta Zool. Mex. (n.s.), 78: $57-74$.

GARDNER, A. L., 1977, Feeding habits, pp. 293-350. In: R. J. Barker, J. K. Jones Jr. \& D. C. Carter (eds.), Biology of bats of the New World family Phyllostomatidae, Part II. Spec. Publ. Mus. Texas Tech. Univ., 13: 1-364. 
GRIBEL, R. \& HAY, J. D., 1993, Pollination ecology of Caryocar brasiliense (Caryocaraceae) in Central Brazil cerrado vegetation. J. Trop. Ecol., 9: 199-211.

HEITHAUS, S. R., FLEMING, T. H. \& OPLER, P. A., 1975, Foraging patterns and resource utilization in seven species of bats in a seasonal tropical forest. Ecology, 56: 841-854.

HERNANDEZ, C. S., TAPIA, C. B. C., GARDUNO, A. N., CORONA, C. \& HIDALGO, M. A. G., 1985, Notes on distribution and reproduction of bats from coastal regions of Michoacan, Mexico. J. Mamm., 66(3): 549-553.

MARQUES, S. A., 1985, Novos registros de morcegos do Parque Nacional da Amazônia (Tapajós) com observações do período de atividade noturna e reprodução. Bol. Mus. Par. Emílio Goeldi Sér. Zool., 2(1): 71-83.

MARQUES, S. A., 1986, Activity cycle, feeding and reproduction of Molossus ater (Chiroptera, Molossidae) in Brazil. Bol. Mus. Par. Emílio Goeldi Sér. Zool., 2(2): 159-179.

MARQUES, R. V. \& FABIÁN, M. E., 1994, Ciclo reprodutivo de Tadarida brasiliensis (I. Geoffroyi, 1824) (Chiroptera, Molossidae) em Porto Alegre, Brasil. Iheringia (Sér: Zool.), 77: $45-56$

MELLO, M. A. R. \& FERNANDEZ, F. A. S., 2000, Reproductive ecology of the bat Carollia perspicillata (Chiroptera: Phyllostomidae) in a fragment of the Brazilian Atlantic coastal forest. Z. Säugetier, 65: 340-349.

NEUWEILER, G., 2000, The biology of bats. Oxford University Press, 310p.

OLIVEIRA, P. E., 1998, Fenologia e biologia reprodutiva das espécies de cerrado, pp. 169-172. In: S. M. Sano \& S. P. Almeida (eds.), Cerrado - ambiente e Flora. Embrapa, Planaltina, DF, 566p

RACEY, P. A., 1982, Ecology of bat reproduction, pp. $57-$ 104. In: T. H. Kunz (ed.), Ecology of bats. Plenum Press, New York and London, 425p.

REIS, S. F., 1989, Biologia reprodutiva de Artibeus lituratus (Olfers, 1818) (Chiroptera: Phyllostomidae). Rev. Bras. Biol., 49(2): 369-372.
RIVAS-PAVA, P., SÁNCHEZ-PALOMINO, P. \& CADENA, A., 1996, Estructura trófica de la comunidad de quirópteros en bosques de galería de la serranía de la Macarena (Meta Colombia). pp. 237-248. In: Contributions in mammalogy: a memorial volume honoring Dr. J. Knox Jones, Jr. Mus. Texas Tech. Univ., 315p.

SAZIMA, M., BUZATO, S. \& SAZIMA, I., 1999, Batpollinated flower assemblages and bat visitors at two Atlantic Forest sites in Brazil. Ann. Bot., 83: 705-712.

SOKAL, R. R. \& ROHLF, J. F., 1981, Biometry: the principles and practice of statistics in biological research. $2^{\text {nd }}$ ed., W. H. Freeman and Company, San Francisco, 859p.

TAMSITT, J. R. \& VALDIVIESO, D., 1961, Notas sobre actividades nocturnas y estados de reproducción de algunos quirópteros de Costa Rica. Rev. Biol. Trop., 9(2): 219-225.

TADDEI, V. A., 1976, The reproduction of some Phyllostomidae (Chiroptera) from the northwestern region of the State of São Paulo. Bol. Zool. Univ. São Paulo, 1: 313-330.

TADDEI, V. A., 1980, Biologia reprodutiva de Chiroptera: perspectivas e problemas. Inter-Facies, Escr. e Doc., 6: $1-18$.

TADDEI, V. A., 1996, Sistemática de quirópteros. Bol. Inst. Pasteur, 1(2): 3-15.

TRAJANO, E., 1985, Ecologia de populações de morcegos cavernícolas em uma região cárstica do Sudeste do Brasil. Revta. Bras. Zool., 2(5): 255-320.

WILLIG, M. R., 1985, Reproductive patterns of bats from caatingas and cerrado biomes in northeastern Brazil. $J$. Mamm., 66(4): 667-681.

WILliG, M. R., CAMILO, G. R. \& NOBLE, S. J., 1993, Dietary overlap in frugivorous and insectivorous bats from edaphic cerrado habitats of Brazil. J. Mamm., 74(1): 117-128.

WILSON, D. E., 1979, Reproductive patterns, pp. 317-378. In: R. J. Barker, J. K. Jones Jr. \& D. C. Carter (eds.), Biology of bats of the New World family Phyllostomatidae, Part III. Spec. Publ. Mus. Texas Tech. Univ., 16: 1-441. 